\title{
Knowledge, attitude and practice of pregnant women on gender preference, prenatal sex determination and female feticide
}

\author{
Gitanjali Kapoor ${ }^{1}$, Dinesh Kumar ${ }^{2 *}$
}

\author{
${ }^{1}$ Assistant Surgeon, CHC Marh, Jammu, Jammu and Kashmir, India \\ ${ }^{2}$ Senior resident, SMGSH, Government Medical College, Jammu, Jammu and Kashmir, India
}

Received: 08 February 2017

Accepted: 23 February 2017

\author{
*Correspondence: \\ Dr. Dinesh Kumar, \\ E-mail: highcourtnaresh@gmail.com
}

Copyright: () the author(s), publisher and licensee Medip Academy. This is an open-access article distributed under the terms of the Creative Commons Attribution Non-Commercial License, which permits unrestricted non-commercial use, distribution, and reproduction in any medium, provided the original work is properly cited.

\begin{abstract}
Background: Sex ratio is defined as the number of females per thousand males. The objectives were to study the knowledge, attitude and the practice of pregnant women on gender preference, prenatal sex determination and female feticide.

Methods: It was a hospital based cross-sectional study. The present study was undertaken among the 204 newly registered pregnant women attending the hospital in Marh block of Jammu district, Jammu and Kashmir, India. A predesigned, pre-tested and structured questionnaire was used in the study. The data collection technique was a personnel interview of the study subjects.

Results: The mean age of study subjects was $25.39 \pm 3.6$ years. A majority $(75.5 \%)$ of the pregnant women did not show any gender preference, followed by male preference (13.73\%) and female preference (10.78\%). Only $70.59 \%$ and $67.65 \%$, of the total subjects were aware that prenatal sex determination and female feticide are illegal, respectively. Awareness regarding prenatal sex determination and female feticide increased with the level of education.

Conclusions: There is a need to educate pregnant women about the impact of negative sex ratio on the society and about the penalization for violation of the PCPNDT act.
\end{abstract}

Keywords: Attitude and practice, Female feticide, Gender preference, Knowledge, Prenatal sex determination

\section{INTRODUCTION}

Sex ratio is defined as the number of females per thousand males. It is an important and useful indicator to assess relative excess or deficit of men or women in a given population at that point of time. Changes in sex ratio reflect underlying socio economic and cultural patterns of a society. ${ }^{1}$ As per 2011 census, the sex ratio in India is 940 females per 1000 of males. In Jammu and Kashmir, India it is 883 females per 1000 of males which is a great alarm. ${ }^{2}$
The birth of female child is perceived as a curse with economic and social liability. ${ }^{3}$ Skewed sex ratio is an issue of major concern and has long-term social and demographic consequences.

The problem is getting worse as scientific methods of detecting the sex of the foetus and for termination of pregnancy are improving. ${ }^{4}$ The proliferation and abuse of advanced technologies coupled with social factors such as dowry, concerns with family name and looking up to the son as a breadwinner, contributing to the low status of women, have made the evil practice of female feticide common in the middle and higher socioeconomic 
households, more so in the north Indian states including Jammu and Kashmir. ${ }^{5}$ Female feticide resulting in a decline of the child sex ratio has led to enforcement of Preconception and prenatal diagnostic techniques (PCPNDT) act since February 2003. ${ }^{6}$

Keeping the alarmingly less sex ratio in our state in mind, we have come up with this study to test knowledge, attitude and practice of pregnant women on gender preference, prenatal sex determination and female feticide.

\section{METHODS}

A cross-sectional hospital based descriptive study was undertaken with 204 pregnant women who attended the antenatal clinic (ANC) of community health centre, Marh, Jammu and Kashmir, India. The study was carried out from September 2016 to December 2016. The sampling frame was the newly registered pregnant women attending the ANC OPD on the three days of the week.

A systematic random samplings method was employed to select the subjects wherein every alternate newly registered pregnant woman attending the ANC OPD was selected for the study. Only pregnant women were included in the study, pregnancy being defined as history of amenorrhea coupled with a positive urine hCG test and/are ultrasonologically confirmed pregnancy, or history of amenorrhea coupled with a clinically confirmed pregnancy.

A pre-tested and pre-structured questionnaire was used to collect information on the knowledge, attitude and practice of pregnant women on gender preference, prenatal sex determination and female feticide. Verbal consent was taken before filling the questionnaire. Strict confidentiality of the data and privacy of the patients was maintained. Data were entered in microsoft excel and analyzed using open Epi Info for windows.

The Chi square test for proportions was used as the test of significance. Two-tailed p-value of less than 0.05 was considered significant.

\section{RESULTS}

The mean age of the study subjects was $25.39 \pm 3.6$ years. A majority $47.09 \%$ were educated beyond $10^{\text {th }}$ followed by $45.1 \%$ who were educated upto $10^{\text {th }}$ and $7.8 \%$ were illiterate. Table 1 shows that about $2 / 3^{\text {rd }}(75.5 \%)$ of the pregnant women did not show any gender preference, followed by male preference $(13.73 \%)$ and female preference $(10.78 \%)$

The association between gender preference and education was found significant with $\mathrm{p}=0.01$. When the 28 women who preferred male child were asked about the reasons for their preference $85.71 \%$ citied the reasons that they were already having female children before and now to balance the family, they desire a male child. Among the other reasons given were that boys propagate the family name $(21.4 \%)$ and they can depend on son in old age $14.2 \%$. When the 22 women who preferred a female child were asked the reasons for their preference, $68.18 \%$ replied that they already have male children and for balancing the family, they want female child. Other reasons which were given that females take good care of parents as compared to males $(31.8 \%)$.

Table 1: Association between gender preference and education status.

\begin{tabular}{|c|c|c|c|c|c|c|}
\hline $\begin{array}{l}\text { Education } \\
\text { status }\end{array}$ & $\begin{array}{l}\text { No preference n } \\
(\%)\end{array}$ & $\begin{array}{l}\text { Male preference } \\
\text { n }(\%)\end{array}$ & $\begin{array}{l}\text { Female preference } \\
\text { n }(\%)\end{array}$ & total & $\begin{array}{l}\text { Chi square } \\
\text { (d.f.) }\end{array}$ & p-value \\
\hline Illiterate & $8(50 \%)$ & $6(37.5 \%)$ & $2(12.5 \%)$ & 16 & \multirow{4}{*}{ 13.1(4) } & \multirow{4}{*}{$0.01^{*}$} \\
\hline Upto $10^{\text {th }}$ & $72((78.26)$ & $14(15.22)$ & $6(6.52)$ & 92 & & \\
\hline Beyond $10^{\text {th }}$ & $74(77.08)$ & $8(8.33)$ & $14(14.58)$ & 96 & & \\
\hline Total & $154(75.5)$ & $28(13.7)$ & $22(10.78)$ & 204 & & \\
\hline
\end{tabular}

*Significant.

Table 2: Association between the awareness that prenatal diagnostic test and female feticide are illegal with the education status.

\begin{tabular}{|c|c|c|c|c|c|c|}
\hline \multirow[b]{2}{*}{$\begin{array}{l}\text { Education } \\
\text { status }\end{array}$} & \multicolumn{3}{|c|}{ Prenatal diagnostic test is illegal } & \multicolumn{3}{|c|}{ Female feticide is illegal } \\
\hline & $\begin{array}{l}\text { Aware no. } \\
(\%)\end{array}$ & $\begin{array}{l}\text { Not aware no. } \\
(\%)\end{array}$ & $\begin{array}{l}\text { Chi square } \\
\text { (d. f.), p value }\end{array}$ & $\begin{array}{l}\text { Aware no. } \\
(\%)\end{array}$ & $\begin{array}{l}\text { Not aware no. } \\
(\%)\end{array}$ & $\begin{array}{l}\text { Chi square } \\
\text { (d. f.), p value }\end{array}$ \\
\hline Illiterate & $4(25)$ & $12(75)$ & \multirow{4}{*}{$\begin{array}{l}45.3(2) \\
<0.001 *\end{array}$} & $4(25)$ & $12(75)$ & \multirow{4}{*}{$\begin{array}{l}51.6(2) \\
<0.001 *\end{array}$} \\
\hline Upto $10^{\text {th }}$ & $52(56.5)$ & $40(43.5)$ & & $46(50)$ & $46(50)$ & \\
\hline Beyond $10^{\text {th }}$ & $88(94.7)$ & $8(8.3)$ & & $88(94.7)$ & $8(8.3)$ & \\
\hline Total & $144(70.5)$ & $60(29.5)$ & & $138(67.6)$ & $66(32.4)$ & \\
\hline
\end{tabular}

*Significant. 
When it was asked why they did not go for sex determination, $45.09 \%$ told that both boys and girls are equal, $30.4 \%$ told that it is God's will, $10.8 \%$ told that it is illegal and $5.9 \%$ told that it is a sin to detect the gender of the child before birth.

Association between the awareness that pre-natal diagnostic test and female feticide are illegal with education status is shown in Table 2. $70.59 \%$ women were aware that prenatal diagnostic test is illegal and association of this with educational status was found highly significant $(\mathrm{p}<0.001) .67 .65 \%$ women were aware that female feticide is illegal and association of this with educational status was highly significant $(p<0.001)$. When asked whether they would go for female feticide if they could know that the fetus is a female, all the women responded in the negative.

On trying to explore the reasons for not going for a female feticide if female fetus in utero, the majority $40.7 \%$ women told that both boys and girls are equal. Other reasons given were that it is God's will (26\%), it is illegal $(13.7 \%)$, it is $\sin (10.8 \%)$. Some responded that they are themselves females $(6.9 \%)$. When asked about the social consequences of female feticide, out of the 118 , who responded, $45 \%$ said that it will result in social imbalance, $35 \%$ said that men would not find bride for marriage and $20 \%$ said that families cannot be run.

Television (63.7\%) followed by print media (31.9\%) were the main source of information regarding female feticide for the study subjects followed by friends/relatives $(17.2 \%)$.

\section{DISCUSSION}

Mean age of the subjects in our study was $25.39 \pm 3.6$ years which is similar to study by Kansal R et al in which the mean age was $23.98 \pm 3.02$ years. ${ }^{5}$ A majority $47.09 \%$ were educated beyond 10th followed by $45.1 \%$ who were educated upto $10^{\text {th }}$ and $7.8 \%$ were illiterate whereas in study by Kansal R et al majority $(43.8 \%)$ were educated upto high school and $22.2 \%$ were illiterate. ${ }^{5}$ About $2 / 3^{\text {rd }}$ $(75.5 \%)$ of the pregnant women did not show any gender preference, followed by male preference $(13.73 \%)$ and female preference $(10.78 \%)$. This is similar to study by Kansal R et al in which about two thirds $(66 \%)$ of the pregnant women did not show any gender preference, followed by male preference $(22.2 \%)$ and female preference $(11.8 \%){ }^{5}$ This finding is in contrast to that reported by Vadera et al and Puri et al who reported male preference as $58.5 \%$ and $56 \%$ respectively. ${ }^{4,7}$ When the 28 women who preferred male child were asked about the reason for their preference $85.71 \%$ citied the reasons that they were already having female children before and now to balance the family, they desire a male child.

When the 22 women who preferred a female child were asked the reasons for their preference, $68.18 \%$ replied that they already have male children and for balancing the family, they want female child. It seems that a balanced family, i.e. having both sons and daughters in the family was more preferred among the respondents rather than having a strong unidirectional preference for male child. Those who were having female children preferred male child and those having male children preferred female child, Puri et al and Kansal R et al had reported a similar finding., $70.59 \%$ women were aware that prenatal diagnostic test is illegal and association of this with educational status was found highly significant $(\mathrm{p}<0.001)$. $67.65 \%$ women were aware that female feticide is illegal and association of this with educational status was highly significant $(\mathrm{p}<0.001)$. This is similar to study by Kansal R et a who found $84.7 \%$ women were aware that prenatal diagnostic test is illegal and $89.7 \%$ women were aware that female feticide is illegal and the association of both with education was found statistically significant $\mathrm{p}<0.001 .^{5}$

In present study no women told that they would go for female feticide whereas in study by Kansal R et al $92.6 \%$ responded in the negative. ${ }^{5}$ In present study, when asked about the social consequences of female feticide, out of the 118 , who responded, $45 \%$ said that it will result in social imbalance, $35 \%$ said that men would not find bride for marriage and $20 \%$ said that families cannot be run whereas, in study by Kansal R et al, $36.28 \%$ women gave reason of social imbalance followed by $34.6 \%$ gave the reason that men would not find bride for marriage. ${ }^{5}$ Similarly to present study, television was the main source of information for female feticide in the study by Kansal $\mathrm{R}$ et al and Sharmila $\mathrm{C}$ et al. ${ }^{5,8}$

\section{CONCLUSION}

There is a need to educate pregnant women about the impact of negative sex ratio on the society and about the penalization for violation of the PCPNDT act. Society should be made aware that girls are equal to boys in every field. It is also not wise to go after balancing the family and in doing that producing more and more children. Those who are engaged in malpractice of prenatal sex determination and female feticide should be strictly dealt under law.

Funding: No funding sources Conflict of interest: None declared

Ethical approval: The study was approved by the Institutional Ethics Committee

\section{REFERENCES}

1. Census of India. Gender composition. Available at http:// censusindia.gov.in/ census_And_You/ gender_composition.aspx. Accessed on 21 January 2017.

2. Office of Registrar General and Census Commissioner, India. Population in age group 0-6 years by sex and sex ratio (0-6). Available at: http:// 
www.censusindia.gov.in /2011-prov-results/ indiaatg lance.html. Accessed on 21 January 2017.

3. Kanitkar T, Mistry M. Status of women in India-an interstate comparison. Indian J Soc Work. 2000;61:381-3.

4. Vadera BN, Joshi UK, Unadakat SV, Yadav BS, Yadav S. Study on knowledge, attitude and practices regarding gender preference and female feticide among pregnant women. Indian $\mathrm{J}$ Comm Med. 2007;32:300-1.

5. Kansal R, Maroof KA, Bansal R, Parashar P. A hospital based study on knowledge, attitude and practice of pregnant women on gender preference, prenatal sex determination and female feticide. Indian J Public Health. 2010;54:209-12.

6. Bhaktwani A. The PC-PNDT act in nutshell. Indian J Radiol Imaging. 2012;22(2):133-4.
7. Puri S, Bhatia V, Swami HM. Gender preference and awareness regarding sex determination among married women in slums of Chandigarh. Indian $\mathbf{J}$ Comm Med. 2007;32:60-2.

8. Sharmila V, Babu TA, Singh D. Knowledge, awareness and attitude about prenatal sex determination, pre- conception and pre-natal diagnostic techniques act among pregnant women in the South Indian union territory of Puducherry. Int $\mathbf{J}$ Reprod Contracept Obstet Gynecol. 2016;5:3470-4.

Cite this article as: Kapoor G, Kumar D.

Knowledge, attitude and practice of pregnant women on gender preference, prenatal sex determination and female feticide. Int J Reprod Contracept Obstet Gynecol 2017;6:1196-9. 